BIS WORKING PAPERS

No. 76 - October 1999

\title{
THE PRICE OF RISK AT YEAR-END: \\ EVIDENCE FROM INTERBANK LENDING
}

by

Craig H Furfine

BANK FOR INTERNATIONAL SETTLEMENTS

Monetary and Economic Department

Basel, Switzerland 
BIS Working Papers are written by members of the Monetary and Economic Department of the Bank for International Settlements, and from time to time by other economists, and are published by the Bank. The papers are on subjects of topical interest and are technical in character. The views expressed in them are those of their authors and not necessarily the views of the BIS.

Copies of publications are available from:

Bank for International Settlements

Information, Press \& Library Services

CH-4002 Basel, Switzerland

Fax: +41 61 / 2809100 and +4161 / 2808100

This publication is available on the BIS website (www.bis.org).

(C) Bank for International Settlements 1999.

All rights reserved. Brief excerpts may be reproduced or translated provided the source is stated. 


\title{
BIS WORKING PAPERS
}

No. 76 - October 1999

\section{THE PRICE OF RISK AT YEAR-END: EVIDENCE FROM INTERBANK LENDING}

by

Craig H Furfine *

\begin{abstract}
This paper analyses Risk premia on overnight interbank loans increase by a factor of 13 at year-end. Further, this finding is not consistent with common theories of similar year-end anomalies in other money markets. In particular, seasonal liquidity demands seem to explain only a fraction of the effect. Although evidence of yearend window dressing is found in the interbank market, such activity cannot explain the change in pricing behaviour because information about the risk of interbank loans is never publicly disclosed.
\end{abstract}

* The author would like to acknowledge helpful comments from James Hamilton and colleagues at the Bank for International Settlements. 



\section{Contents}

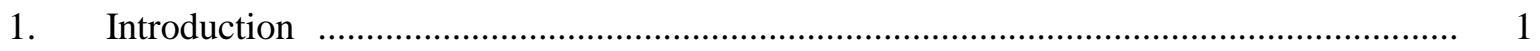

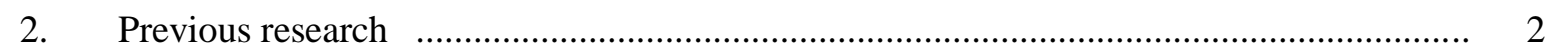

3. The federal funds market, bank reserves and liquidity $\quad$..................................................... 4

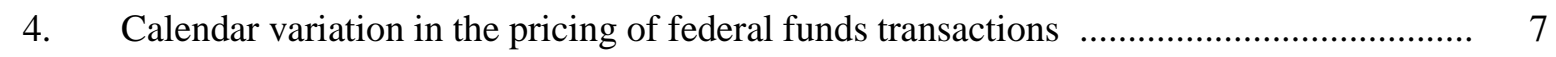

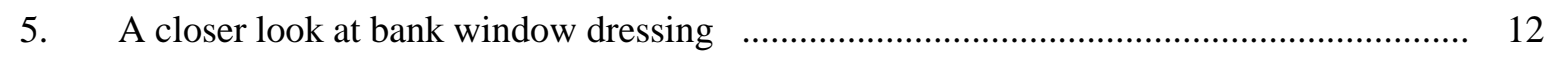

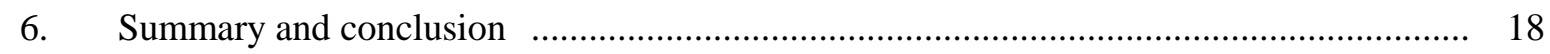

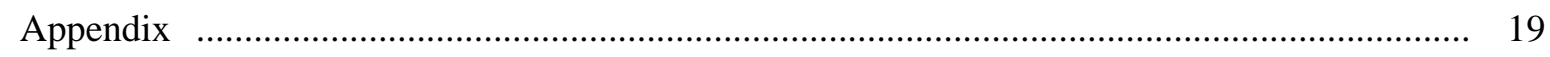

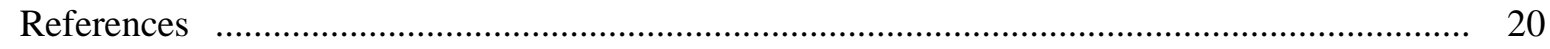





\section{Introduction}

Extensive research has examined the behaviour of financial markets around calendar events generally, and has focussed on the apparent anomalous behaviour around year-end in particular. This paper extends previous work by studying the year-end behaviour of the federal funds market, the market where banks borrow and lend cash (reserves) on an overnight basis. Relative to other financial markets, the funds market offers many advantages to understanding the impact of the year-end. First, this market is an overnight market. ${ }^{1}$ Thus, any anomalous year-end effects would show up on a single day, 31 December. Second, the funds market is where banks balance their demand for funds against their own liquidity needs and the liquidity needs of their customers, offering a natural environment to test the preferred habitat explanation for the year-end behaviour of money markets offered by Griffiths and Winters (1997). Third, the cross-sectional variation in interest rates charged in the funds market can be explicitly used to correlate the relationship between interest rates paid and borrower risk, allowing one to look for a flight from risk consistent with Musto (1997). Finally, the funds market is a good place to detect banks engaging in window dressing as first documented by Allen and Saunders (1992).

There are three main empirical results in this paper. First, evidence is presented suggesting that in the absence of Fed intervention, the federal funds rate would tend to spike on the last day of the year. This finding complements Hamilton's (1996) finding that the uncertainty in the funds rate increases by 30 times on the last day of the year, even though the level of the federal funds rate is expected to be unchanged. In particular, the lack of a predictable year-end increase in the funds rate is traced to a contemporaneous large increase in banking system reserves. A similar increase in reserves does not predictably occur at the end of any other month, and the funds rate rises by as much as 68 basis points on these dates.

The second main empirical result is that the sensitivity of federal funds transaction interest rates to proxies for borrower risk increases dramatically on the last day of the year, with similar but smaller increases at quarter-end and month-end. It is estimated that this repricing would cause a risky bank to pay 93.5 basis points more than a safe bank to borrow funds on the last day of the year, although this risk premium is only 6.6 basis points on normal days. Further, it is argued that this finding is unrelated to bank disclosure requirements (Musto $(1997,1999)$ ) or seasonally high demands for liquidity (Griffiths and Winters (1997)).

According to a Federal Reserve Bank of New York (1987) survey, 96\% of federal funds loans were for an overnight maturity. 
The third main empirical finding is that the probability that a bank participates in the federal funds market increases noticeably at year-end, suggesting the tendency of banks to use the funds market to alter their balance sheet ahead of quarterly disclosure dates. Despite this behaviour, the paper concludes that the change in market participants that occurs at year-end cannot explain the repricing of risk.

The rest of the paper is organised as follows. Section 2 briefly reviews the previous literature on yearend movements in financial markets. The next three sections document the three main empirical conclusions in turn. Section 3 documents the behaviour of the federal funds rate, bank reserves, and payment flows around special calendar events. Section 4 presents regression results demonstrating that a risky borrower of federal funds pays a much higher interest rate on 31 December than a similarly risky borrower on any other day. Section 5 documents the relationship between funds market participation and specific calendar dates and shows that this relationship does not drive the findings of Section 4. Section 6 concludes.

\section{Previous research}

Much of the interest in calendar anomalies stems from Keim (1983), who finds that stock returns of small firms outperform those of large firms in January. One possible explanation of this empirical regularity is tax-loss selling. Because capital gains can be partially offset by capital losses, individual investors subject to these taxes may have an incentive to sell losing stocks in December and repurchase them in January.

Many authors have lent empirical support to the tax-loss selling hypothesis. Givoly and Ovadia (1983) find that recent losers have a larger turn-of-the-year effect. Badrinath and Lewellen (1991) document an increase in loss-taking trades near the end of the year. Griffiths and White (1993) exploit the difference in the Canadian tax year-end and calendar year-end to argue that taxes drive the tendency for stocks to trade at the bid rather than the ask price. Sias and Starks (1997) document that stocks with greater individual interest, and therefore a greater exposure to capital gains taxation, have a greater year-end effect.

Despite the evidence supporting a tax-related cause of the January effect, research has also persuasively argued that taxes cannot be the complete answer. In particular, Jones et al. (1987) show that the January effect existed in the United States before capital gains taxation and Gultekin and Gultekin (1983) find a calendar-year effect in countries where the tax year-end is different from the calendar year-end.

Because taxes appear to be only a partial explanation for the puzzling year-end behaviour of stocks, other research has explored Keim's (1983) suggestion that the anomalous January performance of 
small firm stocks reflects a flight from risk at year-end. Small firms are generally riskier than larger firms, and thus Keim's (1983) findings are consistent with investors selling small company stocks in December and buying them again in January.

One possible explanation of this flight from risk is Haugen and Lakonishok's (1988) window dressing hypothesis. They argue that portfolio managers have an incentive to window dress their investments away from riskier holdings prior to year-end disclosure dates. These year-end portfolio adjustments are sufficiently important to depress the price of riskier stocks in December and give these same stocks an added boost in January.

To consider this and other non-tax-related explanations to the year-end anomaly, other research has focussed on the behaviour of prices in money and government bond markets since instruments traded in these markets are not subject to capital gains taxation. Park and Reinganum (1986) document that government bonds that mature across the end of the year trade at a substantial discount. That is, these instruments contain an additional premium in their yield that is related to the end of the calendar year. Because government bonds are subject only to income taxes, and because investors presumably wish to defer such taxes by buying bonds maturing in the following calendar year, Park and Reinganum present these results as a puzzle that requires theories unrelated to taxation for explanation.

Musto (1997) finds that commercial paper that matures across year-end also contains a substantial risk premium that is increasing both with maturity and with the credit risk of the instrument. These results provide convincing evidence that either the amount of risk or the price to bear risk increases at yearend. Consistent with the latter explanation, Musto finds that intermediaries with predominantly 31 December fiscal year-ends show evidence of window dressing, consistent with the notion that commercial paper spreads around year-end are being driven by market participants shying away from holding riskier instruments at the time of mandatory public portfolio disclosures. In further work, Musto (1999) distinguishes between retail and wholesale money funds as a proxy for the ease with which the funds' investment decisions are observed. Consistent with window dressing, Musto (1999) finds that the degree to which funds shift their portfolio towards safer assets around disclosure dates is related to the degree to which such behaviour can be observed by the funds' investors.

Although Musto's $(1997,1999)$ evidence suggests the importance of window dressing, Griffiths and Winters (1997) argue that a window dressing flight from risk, while possibly important, cannot explain the entire puzzle found in money market interest rates at year-end. They present evidence that shows the same empirical regularity in government bond-backed repurchase agreements, an essentially riskfree instrument. Window dressing intermediaries wishing to hide risk-taking, they argue, need not eliminate such instruments from their portfolio. Because their finding is not consistent with a general flight from risk, they argue that the findings in the repo markets are more consistent with Ogden's $(1987,1990)$ seasonal demands for cash arguments. In particular, firms require cash at or near year- 
end to meet seasonally high payment requirements. As a result, any non-cash financial instrument maturing across the year-end will trade at a discount.

Thus, the empirical investigations into year-end patterns in money market rates have found evidence supporting a window dressing-induced flight from risk as well as a general flight to cash. A natural place to examine both of these theories, therefore, would be a market for short-term cash. The federal funds market, where banks trade overnight cash (reserves) with one another, is such a market.

\section{The federal funds market, bank reserves and liquidity}

This section documents the statistical regularities in bank reserves and bank payment flows and relates these findings to Hamilton's (1996) conclusions regarding regularities in the federal funds rate. The daily effective federal funds rate, a value-weighted average interest rate of funds transactions facilitated by brokers surveyed daily by the Federal Reserve, is published by the central bank. The other data used in this section come from the confidential Daylight Overdraft Report Pricing System (DORPS) maintained since 27 May 1993 by the Federal Reserve to monitor banks' compliance with the central bank's payment system risk policies. This database records, among other things, an institution's reserve balance at the start and end of each business day (and every minute in-between) and each bank's payment flows across a variety of payment systems.

Table 1

Calendar patterns in reserves, the federal funds rate and payment flows

\begin{tabular}{|c|c|c|c|c|}
\hline \multirow[b]{2}{*}{ Independent variable } & \multicolumn{4}{|c|}{ Dependent variable } \\
\hline & $\begin{array}{l}\text { Effective federal } \\
\text { funds rate - Target }\end{array}$ & $\begin{array}{l}\text { Log of aggregate } \\
\text { reserve balances }\end{array}$ & $\begin{array}{l}\text { Log of total } \\
\text { Fedwire funds } \\
\text { transfers }\end{array}$ & $\begin{array}{l}\text { Effective federal } \\
\text { funds rate - Target }\end{array}$ \\
\hline \multirow[t]{2}{*}{$1^{\text {st }}$ lag of dependent variable } & 0.188 & 0.344 & 0.416 & 0.158 \\
\hline & $(0.092)^{*}$ & $(0.035)^{* *}$ & $(0.028)^{* *}$ & $(0.091)^{*}$ \\
\hline \multirow[t]{2}{*}{$2^{\text {nd }}$ lag of dependent variable } & -0.036 & 0.055 & 0.028 & -0.055 \\
\hline & $(0.044)$ & $(0.034)$ & $(0.021)$ & $(0.043)$ \\
\hline \multirow[t]{2}{*}{$3^{\text {rd }}$ lag of dependent variable } & 0.011 & 0.064 & 0.068 & 0.006 \\
\hline & $(0.035)$ & $(0.034)^{*}$ & $(0.017)^{* *}$ & $(0.035)$ \\
\hline \multirow[t]{2}{*}{ Day before 1 day holiday } & 0.124 & -0.026 & -0.009 & 0.128 \\
\hline & $(0.134)$ & $(0.030)$ & $(0.035)$ & $(0.133)$ \\
\hline \multirow[t]{2}{*}{ Day before 3 day holiday } & -0.094 & -0.016 & 0.026 & -0.107 \\
\hline & $(0.041)^{*}$ & $(0.013)$ & $(0.013)^{*}$ & $(0.040)^{* *}$ \\
\hline \multirow[t]{2}{*}{ Day after 1 day holiday } & 0.295 & 0.008 & 0.061 & 0.267 \\
\hline & $(0.240)$ & $(0.025)$ & $(0.041)$ & $(0.217)$ \\
\hline \multirow[t]{2}{*}{ Day after 3 day holiday } & 0.264 & 0.037 & 0.205 & 0.178 \\
\hline & $(0.053)^{* *}$ & $(0.020)^{*}$ & $(0.023)^{* *}$ & $(0.053)^{* *}$ \\
\hline \multirow[t]{2}{*}{ First day of non-quarter-beginning months } & 0.069 & 0.029 & 0.087 & 0.005 \\
\hline & $(0.082)$ & $(0.016)^{*}$ & $(0.011)^{* *}$ & $(0.080)$ \\
\hline
\end{tabular}


Table 1 (cont.)

\begin{tabular}{|c|c|c|c|c|}
\hline Last day of non-quarter-ending months & $\begin{array}{l}0.249 \\
(0.044)^{* *}\end{array}$ & $\begin{array}{c}0.031 \\
(0.017)^{*}\end{array}$ & $\begin{array}{l}0.186 \\
(0.011)^{* *}\end{array}$ & $\begin{array}{c}0.165 \\
(0.054)^{* *}\end{array}$ \\
\hline First day of quarter 2,3 , or 4 & $\begin{array}{c}0.223 \\
(0.251)\end{array}$ & $\begin{array}{c}0.039 \\
(0.028)\end{array}$ & $\begin{array}{l}0.120 \\
(0.029)^{* *}\end{array}$ & $\begin{array}{c}0.157 \\
(0.259)\end{array}$ \\
\hline Last day of quarter 1,2 , or 3 & $\begin{array}{l}0.688 \\
(0.157)^{* *}\end{array}$ & $\begin{array}{c}0.030 \\
(0.032)\end{array}$ & $\begin{array}{c}0.316 \\
(0.012)^{* *}\end{array}$ & $\begin{array}{c}0.546 \\
(0.168)^{* *}\end{array}$ \\
\hline First day of the year & $\begin{array}{c}0.266 \\
(0.118)^{*}\end{array}$ & $\begin{array}{c}0.076 \\
(0.041)^{*}\end{array}$ & $\begin{array}{c}0.041 \\
(0.032)\end{array}$ & $\begin{array}{c}0.204 \\
(0.112)^{*}\end{array}$ \\
\hline Last day of the year & $\begin{array}{c}-0.022 \\
(0.283)\end{array}$ & $\begin{array}{c}0.111 \\
(0.051)^{*}\end{array}$ & $\begin{array}{l}0.166 \\
(0.031)^{* * *}\end{array}$ & $\begin{array}{c}-0.121 \\
(0.288)\end{array}$ \\
\hline All other days in December & $\begin{array}{c}0.013 \\
(0.022)\end{array}$ & $\begin{array}{c}0.027 \\
(0.008)^{* *}\end{array}$ & $\begin{array}{c}0.009 \\
(0.008)\end{array}$ & $\begin{array}{c}0.006 \\
(0.023)\end{array}$ \\
\hline $15^{\text {th }}$ of the month & $\begin{array}{c}0.114 \\
(0.021)^{* *}\end{array}$ & $\begin{array}{c}0.048 \\
(0.011)^{* *}\end{array}$ & $\begin{array}{l}0.178 \\
(0.010)^{* *}\end{array}$ & $\begin{array}{c}0.040 \\
(0.029)\end{array}$ \\
\hline Good Friday & $\begin{array}{l}-0.070 \\
(0.089)\end{array}$ & $\begin{array}{c}0.000 \\
(0.039)\end{array}$ & $\begin{array}{l}-0.621 \\
(0.023)^{* *}\end{array}$ & $\begin{array}{c}0.196 \\
(0.119)\end{array}$ \\
\hline Days of the reserve maintenance period & & & & \\
\hline First Thursday & $\begin{array}{l}0.083 \\
(0.019)^{* *}\end{array}$ & $\begin{array}{l}-0.051 \\
(0.012)^{* *}\end{array}$ & $\begin{array}{l}0.045 \\
(0.008)^{* *}\end{array}$ & $\begin{array}{c}0.078 \\
(0.020)^{* *}\end{array}$ \\
\hline First Friday & $\begin{array}{c}0.012 \\
(0.025)\end{array}$ & $\begin{array}{l}-0.017 \\
(0.014)\end{array}$ & $\begin{array}{c}0.005 \\
(0.012)\end{array}$ & $\begin{array}{c}0.026 \\
(0.024)\end{array}$ \\
\hline First Monday & $\begin{array}{l}0.109 \\
(0.026)^{* *}\end{array}$ & $\begin{array}{c}-0.001 \\
(0.011)\end{array}$ & $\begin{array}{l}0.109 \\
(0.007)^{* *}\end{array}$ & $\begin{array}{l}0.079 \\
(0.029)^{* *}\end{array}$ \\
\hline First Tuesday & Baseline & & & \\
\hline First Wednesday & $\begin{array}{c}0.027 \\
(0.014)^{*}\end{array}$ & $\begin{array}{c}0.011 \\
(0.013)\end{array}$ & $\begin{array}{l}0.023 \\
(0.007)^{* *}\end{array}$ & $\begin{array}{c}0.025 \\
(0.013)^{*}\end{array}$ \\
\hline Second Thursday & $\begin{array}{l}0.060 \\
(0.018)^{* *}\end{array}$ & $\begin{array}{c}0.011 \\
(0.012)\end{array}$ & $\begin{array}{l}0.022 \\
(0.007)^{* *}\end{array}$ & $\begin{array}{c}0.060 \\
(0.018)^{* *}\end{array}$ \\
\hline Second Friday & $\begin{array}{l}-0.041 \\
(0.022)^{*}\end{array}$ & $\begin{array}{l}0.037 \\
(0.011)^{* *}\end{array}$ & $\begin{array}{c}0.020 \\
(0.009)^{*}\end{array}$ & $\begin{array}{l}-0.036 \\
(0.021)^{*}\end{array}$ \\
\hline Second Monday & $\begin{array}{l}0.112 \\
(0.020)^{* *}\end{array}$ & $\begin{array}{l}0.030 \\
(0.012)^{* *}\end{array}$ & $\begin{array}{l}0.100 \\
(0.008)^{* *}\end{array}$ & $\begin{array}{c}0.082 \\
(0.021)^{* *}\end{array}$ \\
\hline Second Tuesday & $\begin{array}{l}-0.007 \\
(0.021)\end{array}$ & $\begin{array}{c}0.008 \\
(0.013)\end{array}$ & $\begin{array}{c}0.013 \\
(0.008)\end{array}$ & $\begin{array}{l}-0.011 \\
(0.020)\end{array}$ \\
\hline Second Wednesday (settlement day) & $\begin{array}{l}0.226 \\
(0.048)^{* *}\end{array}$ & $\begin{array}{c}0.136 \\
(0.018)^{* *}\end{array}$ & $\begin{array}{l}0.032 \\
(0.009)^{* *}\end{array}$ & $\begin{array}{c}0.221 \\
(0.046)^{* *}\end{array}$ \\
\hline Time trend & $\begin{array}{c}0.000 \\
(0.000)\end{array}$ & $\begin{array}{c}0.000 \\
(0.000)^{* *}\end{array}$ & $\begin{array}{l}0.000 \\
(0.000)^{* *}\end{array}$ & $\begin{array}{c}0.000 \\
(0.000)^{* *}\end{array}$ \\
\hline Log of total Fedwire funds transfers & & & & $\begin{array}{c}0.459 \\
(0.129)^{* *}\end{array}$ \\
\hline Constant & $\begin{array}{l}-0.067 \\
(0.017)^{* *}\end{array}$ & $\begin{array}{l}13.051 \\
(1.299)^{* *}\end{array}$ & $\begin{array}{l}13.300 \\
(0.850)^{* *}\end{array}$ & $\begin{array}{l}-12.596 \\
(3.527)^{* *}\end{array}$ \\
\hline Observations & 990 & 978 & 978 & 987 \\
\hline
\end{tabular}


As Hamilton (1996) documents, the level of the daily effective federal funds rate does not vary predictably at year-end, and this result is replicated in the first column of Table 1. A linear regression of the spread between the daily effective funds rate and the Federal Reserve's target funds rate on a set of calendar variables over the sample period 27 May 1993 - 7 May 1997 yields conclusions similar to those of Hamilton's more sophisticated econometric approach estimated over a different sample period. In particular, the rate tends to rise noticeably on reserve settlement days. Interestingly, the effective funds rate tends to rise by 68.8 basis points on the last day of the first three quarters and by 24.9 basis points on the last day of all other months except December. In this respect, it is perhaps surprising that the rate shows no predictable movement at year-end.

A partial explanation of this result may be found in the second column of Table 1, which runs the same regression but replaces the dependent variable with the log of total banking system reserves. As this column suggests, over the sample period the Fed systematically increased banking system reserves by around $11.1 \%$ on the last day of the year.

This compares to a predictable $3.1 \%$ increase at the end of non-quarter-end months and no predictable change in reserves at the end of quarter-ending months. Note, too, that this effect cannot be explained by a seasonal increase in reserves. The predicted $11.1 \%$ increase in reserves at year-end is notably larger than the predicted $2.7 \%$ increase in reserves on all other days in December. These results suggest that in the absence of Fed intervention, the federal funds rate would spike upward at year-end, matching the pattern previously documented in repo, bond and commercial paper markets.

The third column documents the seasonal variation in liquidity needs, as proxied by the log of the total daily value of funds transfers over Fedwire, the large-value transfer system operated by the Federal Reserve. This column documents that liquidity needs have seasonal patterns very similar to those of the funds rate, suggestive of a causal link as modelled by Furfine (1998). In particular, aggregate payment value increases by nearly $17 \%$ at year-end. However, this amount is less than what typically occurs at the end of the first three quarters of the year and is not statistically different from the predicted increase in payment value that occurs at the end of any other month. Thus, if liquidity concerns were responsible for the year-end movements in money market rates, one might expect that an effect at least as large as the year-end movement would arise at the end of all other months.

The final column of Table1 reruns the initial funds rate regression, this time including the log of funds transfers as an independent variable. Although liquidity needs are correlated with the daily movements in the effective funds rate, predictable movements in the rate remain, suggesting that other factors must be at work. Such factors may include limits on interbank credit lines and transaction costs as proposed by Hamilton (1996), or penalties for overnight overdrafts as suggested by Furfine (1998).

The results in Table 1 suggest three things. First, the funds rate would likely rise at year-end were it not for Fed intervention. Second, there appears to be a link between liquidity needs and interest rates 
at the aggregate level. Third, aggregate liquidity demands alone fail to explain the entire movement of the effective funds rate around special calendar dates.

\section{Calendar variation in the pricing of federal funds transactions}

In this section, the pricing of individual federal funds transactions is explored to determine whether the lack of an apparent year-end premium in the daily effective rate means that there is no year-end change in the behaviour of participants or pricing of transactions in the funds market. The data used in this and the following section were compiled from a record of every Fedwire funds transfer payment made between 17 November 1997 and 10 April 1998. Relatively few of these nearly 40 million transactions are related to the federal funds market. However, since funds transactions are generally settled over Fedwire, one can identify a funds transaction by searching the universe of transactions for a pair of payments between a given pair of banks on adjoining days where the second payment is in the amount of the first payment plus a day's interest. ${ }^{2}$ Because the study is interested in the pricing of risk at year-end, the sample of transactions was limited to those between US commercial banks for which balance sheet data could be obtained from quarterly call reports. ${ }^{3}$ The final sample consisted of 188,511 transactions over the 100 business days.

Table 2 presents the results of a regression analysis where the dependent variable is the interest rate on a given federal funds transaction. Independent variables are grouped into three categories: characteristics of the borrowing bank, characteristics of the lending bank, and characteristics of the transaction. A complete listing and description of the variables included in this regression analysis is given in Table A1 in the Appendix. To isolate the cross-sectional variation in pricing, all regressions included a complete set of dummy variables for the different business days in the relevant sample. ${ }^{4}$ In particular, this captures the fact that on 31 December 1997 the effective federal funds rate (5.84\%) was above the Federal Reserve's target (5.5\%). The sample of transactions was split into six groups: transactions occurring on 31 December 1997 (the only year-end in the sample), those occurring on 31 March 1998 (the only quarter-end), other month-ends, reserve settlement days not otherwise classified, high payment days not otherwise classified, and all other days (normal days). ${ }^{5}$ Each column of Table 2 presents the estimated coefficients for each of the six sub-samples. The coefficients

2 A more complete description of the transaction identification process can be found in Furfine (1999).

3 Approximately $1 \%$ of the remaining transactions were excluded due to extreme outliers reported for some of the participating banks' balance sheet variables.

4 To save space, the results for the day dummies and time-of-day dummies were not reported, but are available separately.

5 High payment days were defined to be days on which Fedwire value was at least as high as that on 31 December 1997 where the day was not included in one of the other special categories. 
Table 2

Calendar variation in the pricing of risk in the federal funds market

\begin{tabular}{|c|c|c|c|c|c|c|}
\hline & & Coeff & icients repre & esent differen & cees from $n$ & tormal \\
\hline & $\begin{array}{c}\text { Normal } \\
\text { days }\end{array}$ & $\begin{array}{c}\text { 31 December } \\
1997\end{array}$ & $\begin{array}{l}31 \text { March } \\
1998\end{array}$ & Month-ends & $\begin{array}{l}\text { Settlement } \\
\text { days }\end{array}$ & $\begin{array}{c}\text { High } \\
\text { payment days }\end{array}$ \\
\hline Borrower characteristics & & & & & & \\
\hline Return on assets & -1.241 & -17.514 & -15.762 & -0.530 & -1.994 & -2.468 \\
\hline & $(0.227)^{* *}$ & $(6.756)^{* *}$ & $(4.066)^{* *}$ & $(1.352)$ & $(1.224)$ & $(0.490)^{* *}$ \\
\hline Nonaccruing loans & 0.248 & 20.822 & -5.293 & 4.545 & 0.800 & 0.197 \\
\hline & $(0.289)$ & $(8.661)^{*}$ & $(3.695)$ & $(1.957)^{*}$ & $(1.366)$ & $(0.668)$ \\
\hline Risk-based capital ratio & -0.369 & -0.380 & -0.561 & -0.116 & 0.071 & -0.207 \\
\hline & $(0.047)^{* *}$ & $(1.587)$ & $(0.811)$ & $(0.347)$ & $(0.232)$ & $(0.137)$ \\
\hline $\log$ (ratio of transaction size to capital) & 0.006 & 0.096 & 0.064 & 0.024 & -0.007 & 0.015 \\
\hline & $(0.001)^{* *}$ & $(0.027)^{* *}$ & $(0.013)^{* *}$ & $(0.007)^{* *}$ & $(0.007)$ & $(0.002)^{* *}$ \\
\hline Market share & 0.001 & 4.803 & 1.665 & 0.443 & -0.321 & 0.230 \\
\hline & $(0.034)$ & $(1.424)^{* *}$ & $(0.466)^{* *}$ & $(0.141)^{* *}$ & $(0.200)$ & $(0.061)^{* *}$ \\
\hline Assets $<\$ 250$ million & 0.119 & -0.278 & -0.091 & -0.144 & 0.140 & 0.008 \\
\hline & $(0.016)^{* *}$ & $(0.452)$ & $(0.124)$ & $(0.136)$ & $(0.091)$ & $(0.030)$ \\
\hline Assets $\$ 250$ million - $\$ 1$ billion & 0.106 & -0.016 & 0.005 & -0.012 & 0.007 & 0.002 \\
\hline & $(0.007)^{* *}$ & $(0.182)$ & $(0.109)$ & $(0.034)$ & $(0.033)$ & $(0.017)$ \\
\hline Assets $\$ 1-\$ 10$ billion & -0.001 & 0.031 & -0.014 & -0.035 & 0.009 & -0.022 \\
\hline & $(0.004)$ & $(0.121)$ & $(0.054)$ & $(0.024)$ & $(0.024)$ & $(0.009)^{*}$ \\
\hline Assets $\$ 10$ - $\$ 100$ billion & -0.022 & -0.039 & -0.026 & -0.023 & 0.004 & -0.014 \\
\hline & $(0.003) * *$ & $(0.085)$ & $(0.035)$ & $(0.017)$ & $(0.018)$ & $(0.007)^{*}$ \\
\hline Assets $>\$ 100$ billion & & Baseline & & & & \\
\hline Dealer bank & 0.006 & -0.079 & -0.121 & -0.064 & 0.005 & -0.035 \\
\hline & $(0.003)^{*}$ & $(0.095)$ & $(0.039)^{* *}$ & $(0.016)^{* *}$ & $(0.019)$ & $(0.006)^{* *}$ \\
\hline Net inflow of payments & -0.008 & -0.009 & -0.060 & 0.005 & -0.019 & 0.021 \\
\hline & $(0.003)$ & $(0.107)$ & $(0.060)$ & $(0.015)$ & $(0.015)$ & $(0.006)^{* *}$ \\
\hline Lender characteristics & & & & & & \\
\hline Market share & -0.238 & -0.715 & 0.072 & 0.459 & -0.427 & -0.488 \\
\hline & $(0.043)^{* *}$ & $(0.845)$ & $(0.326)$ & $(0.224)^{*}$ & $(0.189)^{*}$ & $(0.078)^{* *}$ \\
\hline Assets $<\$ 250$ million & -0.108 & -0.290 & -0.005 & 0.148 & -0.100 & -0.005 \\
\hline & $(0.007)^{* *}$ & $(0.138)^{*}$ & $(0.062)$ & $(0.037)^{* *}$ & $(0.039)^{*}$ & $(0.013)$ \\
\hline Assets $\$ 250$ million - $\$ 1$ billion & -0.117 & -0.427 & -0.030 & 0.133 & -0.116 & -0.005 \\
\hline & $(0.007)^{* *}$ & $(0.140)^{* *}$ & $(0.059)$ & $(0.036)^{* *}$ & $(0.039)^{* *}$ & $(0.013)$ \\
\hline Assets $\$ 1-\$ 10$ billion & -0.088 & -0.334 & -0.015 & 0.115 & -0.099 & -0.008 \\
\hline & $(0.007) * *$ & $(0.136)^{*}$ & $(0.055)$ & $(0.035)^{* *}$ & $(0.039)^{*}$ & $(0.012)$ \\
\hline Assets $\$ 10$ - $\$ 100$ billion & -0.015 & -0.044 & 0.051 & 0.050 & -0.075 & -0.013 \\
\hline & $(0.006)^{*}$ & $(0.107)$ & $(0.043)$ & $(0.029)$ & $(0.035)^{*}$ & $(0.011)$ \\
\hline Assets $>\$ 100$ billion & & Baseline & & & & \\
\hline Dealer bank & 0.000 & -0.258 & 0.007 & 0.008 & 0.009 & 0.014 \\
\hline & $(0.006)$ & $(0.095)^{* *}$ & $(0.037)$ & $(0.025)$ & $(0.029)$ & $(0.010)$ \\
\hline Net inflow of payments & -0.001 & -0.137 & -0.002 & 0.000 & -0.009 & 0.010 \\
\hline & $(0.001)^{* *}$ & $(0.053)^{* *}$ & $(0.006)$ & $(0.005)$ & $(0.004)^{*}$ & $(0.001)^{* *}$ \\
\hline
\end{tabular}


Table 2 (cont.)

\begin{tabular}{|c|c|c|c|c|c|c|}
\hline \multicolumn{7}{|l|}{ Transaction characteristics } \\
\hline Business hours duration & $\begin{array}{c}0.007 \\
(0.001)^{* *}\end{array}$ & $\begin{array}{c}0.023 \\
(0.010)^{*}\end{array}$ & $\begin{array}{c}0.004 \\
(0.005)\end{array}$ & $\begin{array}{l}-0.006 \\
(0.003) *\end{array}$ & $\begin{array}{c}0.004 \\
(0.002)\end{array}$ & $\begin{array}{c}0.001 \\
(0.001)\end{array}$ \\
\hline \multicolumn{2}{|l|}{ Trans size less than or equal to $\$ 10$ mil. } & \multicolumn{5}{|l|}{ Baseline } \\
\hline Trans size between $\$ 10$ mil and $\$ 100$ mil. & $\begin{array}{c}0.005 \\
(0.002)^{*}\end{array}$ & $\begin{array}{l}0.177 \\
(0.064)^{* *}\end{array}$ & $\begin{array}{c}0.013 \\
(0.028)\end{array}$ & $\begin{array}{c}0.042 \\
(0.011)^{* *}\end{array}$ & $\begin{array}{c}0.001 \\
(0.010)\end{array}$ & $\begin{array}{c}0.003 \\
(0.004)\end{array}$ \\
\hline Trans size greater than $\$ 100$ mil. & $\begin{array}{l}-0.032 \\
(0.004)^{* *}\end{array}$ & $\begin{array}{c}0.012 \\
(0.126) \\
\end{array}$ & $\begin{array}{c}-0.108 \\
(0.074)\end{array}$ & $\begin{array}{c}0.034 \\
(0.024) \\
\end{array}$ & $\begin{array}{c}0.014 \\
(0.021)\end{array}$ & $\begin{array}{c}-0.015 \\
(0.010)\end{array}$ \\
\hline Observations & 140156 & 2129 & 2067 & 5604 & 19190 & 19365 \\
\hline R-squared & 0.14 & 0.27 & 0.25 & 0.13 & 0.08 & 0.43 \\
\hline \multicolumn{7}{|l|}{ Robust standard errors in parentheses. } \\
\hline A description of all variables included in th & se regression & $\mathrm{s}$ is given in & able A1 i & e Appendix. & & \\
\hline
\end{tabular}

and standard errors for the "non-normal" days represent the difference from a normal day. That is, an insignificant coefficient in the month-end column means that the estimated effect of that variable at month-end is no different from its effect on a normal day.

The first four variables included in the regression attempt to proxy for the risk of the borrowing bank. These measures are the borrower's return on assets, the borrower's ratio of nonaccruing loans to total loans, the borrower's risk-based capital ratio and the (log of the) ratio of the transaction size to the borrower's capital. The first column of Table 2 reports that on normal days, three of these four variables correlate with transaction interest rates in a way consistent with economic theory. That is, higher profitability, higher capital ratios and lower ratios of transaction size to capital all correlate with lower interest rates. The variable measuring nonaccruing loans does not enter with a statistically significant coefficient on normal days.

Reading across the columns of Table 2 reveals a striking pattern in the change in the pricing of federal funds transactions across year-end, quarter-end and month-end. First, whenever the coefficients on the risk variables report a statistically significant change in the pricing of a transaction, they do so with the correct sign and with a magnitude noticeably greater than that found on normal days. For example, a doubling of the ratio of transaction size to borrower capital correlates with a 0.6 basis point increase in the transaction interest rate on normal days. A similar increase in transaction risk correlates with a 10.2 basis point increase on 31 December 1997, a 7.0 basis point increase on 31 March 1998, and a 3.0 basis point increase at the end of November, January and February. A 0.01 increase in borrower profitability correlates with a 1.24 basis point reduction in loan interest rates on normal days. At yearend and quarter-end, the estimated effect is approximately 15 times larger. Nonaccruing loans do not correlate with interest rates on a normal day, but a 0.01 increase in this ratio correlates with a 20.8 basis point increase in the transaction interest rate at year-end. 
These results suggest a dramatic increase in the pricing of risk at year-end, with a similar repricing of risk, albeit of lesser magnitude, at quarter-end and at month-end. The final two columns attempt to address whether part of this observed change in pricing behaviour at year-end (and to a lesser extent at quarter-end and month-end) can be explained by other factors. Since 31 December 1997 was a reserve settlement day, the same equation was estimated for all other settlement days that were not otherwise special days. No significant change in the way the transactions were priced is found for the four variables that proxy for borrower risk. Exploring the hypothesis of Griffiths and Winters (1997), the regression was estimated for other high-value payment days. While these transactions do show a similar effect qualitatively, the magnitude of the effect is noticeably smaller than what is observed for the end of the year and the ends of quarters and months.

Table 3 summarises the implications of Table 2 with regard to the pricing of risk. This table reports the estimated interest rate that would be paid by banks with differing degrees of risk. A bank in the $10^{\text {th }}$ percentile of risk was defined as a bank whose values for the four variables that proxy for risk were set equal to the $10^{\text {th }}$ percentile in the data where a higher percentile corresponds to a safer bank. These values were multiplied by the relevant coefficient from Table 2. For the "non-normal" days, coefficients representing differences from "normal" that were insignificantly different from zero were set equal to zero. Analogous calculations were completed for the $25^{\text {th }}, 50^{\text {th }}, 75^{\text {th }}$ and $90^{\text {th }}$ percentile, and the results were scaled so that the median-risk bank faced an interest rate equal to the Fed's target rate during the sample period of $5.50 \%$.

Table 3

\section{Projected interest rates as a function of risk}

\begin{tabular}{lcccccc}
\hline \multirow{2}{*}{ Risky } & Percentile of risk & Normal & Year-end & Quarter-end & Month-end & High payment \\
& $10 \%$ & 5.527 & 5.925 & 5.738 & 5.601 & 5.570 \\
& $25 \%$ & 5.515 & 5.712 & 5.620 & 5.552 & 5.537 \\
& $50 \%$ & 5.500 & 5.500 & 5.500 & 5.500 & 5.500 \\
& $75 \%$ & 5.482 & 5.273 & 5.365 & 5.440 & 5.457 \\
Safe & $90 \%$ & 5.462 & 5.064 & 5.232 & 5.384 & 5.413 \\
\hline
\end{tabular}

The results indicate that the repricing of risk on certain calendar days is economically significant in addition to being statistically significant. On normal days, the interest rate spread between the $10^{\text {th }}$ percentile bank and the $90^{\text {th }}$ percentile bank is 6.5 basis points. On 31 December 1997, this risk premium increases by a factor of over 13 to 86.1 basis points. This premium is 50.6 basis points on 31 March 1998, and 21.7 basis points at month-end. Although a similar increase in the pricing of risk occurs on high payment days, the estimated risk premium is only 15.7 basis points.

In addition to the documented change in the pricing of risk in the funds market at the end of the year, quarter and month, the results for the other variables suggest that pricing on these calendar dates penalises large borrowing and borrowing that lasts longer. For instance, the borrower's share of the 
market generally does not influence the interest rate on a funds transaction. However, a 0.01 increase in this variable raises the price of the transaction by 4.8 basis point on 31 December 1997, 1.7 basis point on 31 March 1997, and by 0.4 basis points on other month-ends. This effect is economically significant as borrower market share ranges from a negligible level to nearly 0.13 on these dates. Thus, the banks that borrow the most on these dates tend to pay significantly more than on normal days. With respect to the duration of a loan, normal days price an additional hour of borrowing around 0.7 basis points. This is roughly half what might be expected given the Federal Reserve's fee of 1.5 basis points per hour for daylight overdrafts (Richards (1995)). For borrowing on 31 December 1997, a onehour later repayment the following day correlates with an increase in interest rates of 3 basis points. ${ }^{6}$ A similar repricing of duration is not found on 31 March 1998 and other month-ends actually witness an elimination of the pricing relationship found on normal days.

The regression results also suggest that pricing on special calendar days is more favourable to large lenders at year-end. Whereas the largest lenders generally receive around 10 basis points more than small lenders, this differential increases to as much as 50 basis points on 31 December 1997. A similar yet smaller effect is found on settlement days. In contrast, the largest sellers apparently gain no special pricing advantage on month-ends.

The regressions also include dummy variables identifying borrowers and lenders that are dealer banks, defined as those that both borrowed and lent over $\$ 1$ billion in the market each day. These five institutions tend to pay less for borrowing on month-ends other than 31 December 1997. They also tend to receive less for funds lent at year-end, but since these institutions are all large, this result simply offsets part of the gains that these institutions witness on 31 December 1997.

In addition to isolating transactions on high payment days, the liquidity hypothesis of Griffiths and Winters (1997) was examined by including a measure of each participating bank's liquidity needs in each regression. This was proxied by a variable measuring each bank's net inflow of payments as a fraction of the bank's total payments that day. If the liquidity hypothesis were true, one might expect that banks with lower liquidity needs, e.g. a higher net inflow of payments, would be more ready to sell funds and less inclined to buy funds. In either case, interest rates on the transaction would be lower. For the selling bank, this variable did correlate with a larger reduction in transaction interest rates at year-end than on normal days, although no consistent result was found for quarter-end or month-end transactions.

Although one needs to qualify the results in light of the relatively short sample period, the results in Tables 2 and 3 do suggest that risk in the federal funds market is priced much more aggressively at the end of the year and that this effect cannot be explained by higher demand for liquidity. As Musto

6 Delivery times are controlled for in the time-of-day dummies and therefore higher duration is a proxy for repayment time. 
(1997) points out, such a repricing of risk is consistent with a window dressing motive. However, bank disclosure requirements are not consistent with this explanation. In particular, all banks in the sample are required to publicly file a quarterly call report, which reveals a bank's assets, liabilities, income statement and off-balance sheet items grouped into categories. This report does not require the disclosure of any detailed information regarding funds market transactions. Only quantities of funds bought and sold are routinely disclosed in quarterly bank call reports. ${ }^{7}$ It is therefore difficult to explain the repricing of risk in the funds market at year-end as a window dressing phenomenon.

\section{A closer look at bank window dressing}

Bank disclosure requirements suggest that the repricing of risk in the funds market at year-end is unlikely to reflect individual institutions' desire to alter the risk profile of their funds transactions ahead of call report dates. However, as Allen and Saunders (1992) find, the federal funds and repo markets are the most important markets where banks can alter their balance sheet for window dressing purposes. It is possible, therefore, that the results of Section 4 could be driven by the possibility that the set of institutions participating in the market at year-end could be systematically different from

Figure 1

\section{Hypothetical relationship between window dressing and the estimated price of risk}

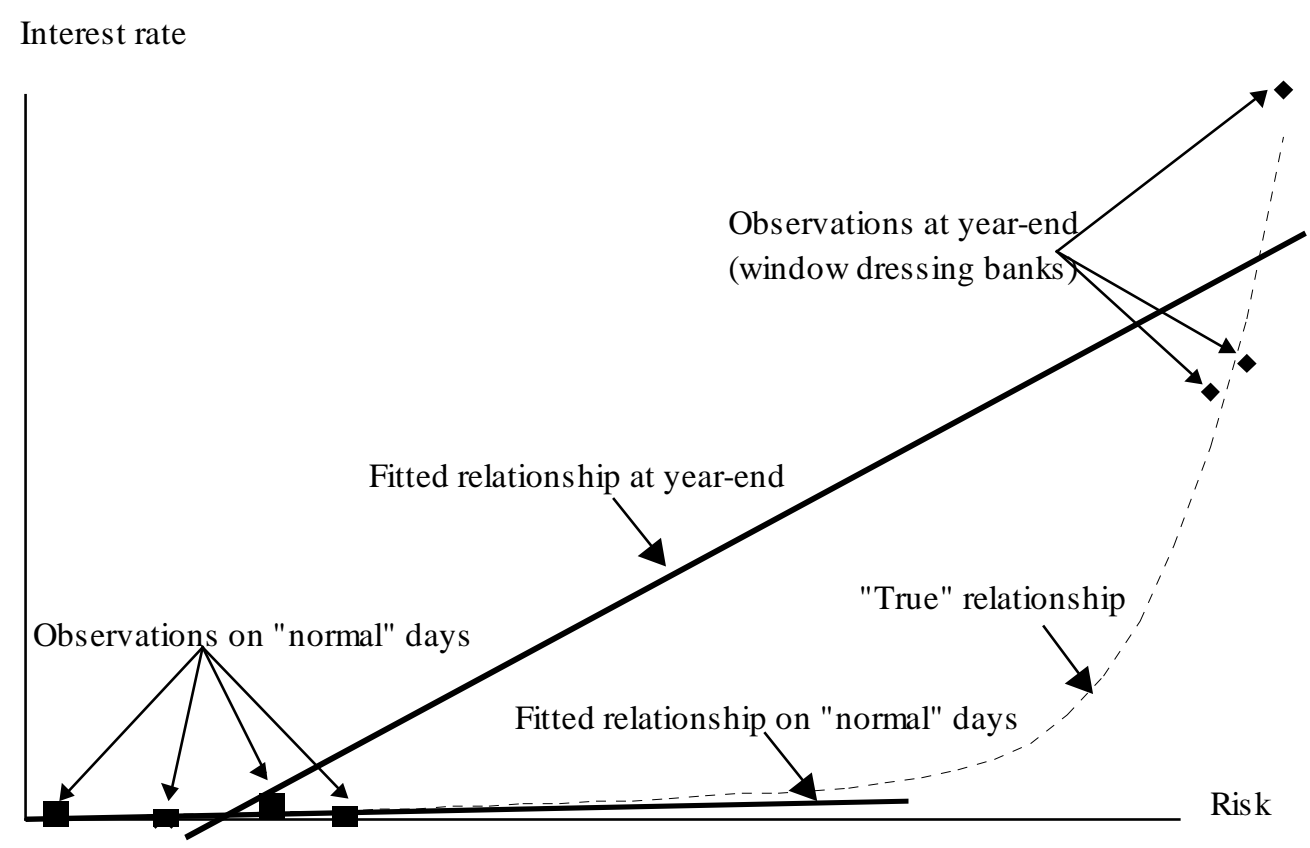

7 The call report requires banks to disclose the total sum of "Federal funds purchased and securities sold under agreements to repurchase" and "Federal funds sold and securities purchased under agreements to resell." 
those participating on other dates. For instance, suppose that riskier banks generally do not borrow in the funds market, either because they are unwilling to borrow at high interest rates or because they are rationed out of the market. Further suppose that these banks, perhaps because they are riskier, especially want to window dress their balance sheets by adding cash and reserves to their assets by borrowing in the funds market ahead of the quarterly filing of bank call reports. For this reason, they try to (and do) participate in the market on certain dates, creating a riskier profile of institutions that participate in the market at year-end and at quarter-end. ${ }^{8}$

Suppose the "true" relationship between risk and interest rates is as depicted in Figure 1. However, the risky banks are only in the sample at year-end. This change in the underlying sample of banks could cause a higher estimated coefficient in my linear pricing model. Therefore, this section tries to identify likely window dressers and explore their potential to influence the results of Table 2 .

The sample of federal funds transactions analysed in the previous section contains 791 institutions that lend at least once in the funds market and 385 institutions that borrow at least once in the funds market during the 100 business days in the sample. However, on any given day during the sample, the number of participating banks may change. Figure 2 graphs the fraction of the 791 sellers that sell and the fraction of the 385 buyers that buy funds on each day of the sample. There does not seem to be an obvious relationship between the participation of selling banks and the end of calendar months. For banks that are borrowing funds, however, the maximum participation rate occurs exactly at year-end, with local peaks occurring at other month-ends.

These overall participation rates may not fully capture window dressing activity because the share of participating banks does not distinguish between those that participate every day and those that only occasionally enter the market. Figure 3 counts the number of participating banks per day when only banks that participate on 10 or fewer days out of the 100 are counted. For both buyers and sellers of funds, this figure peaks on 31 December. That is, for banks that rarely participate in the funds market, the year-end is one day on which they are generally more likely to participate, consistent with the window dressing story of Allen and Saunders (1992).

To explore the relationship between market participation and calendar events formally, one can define a variable equal to 1 for a bank that borrows (or lends) in the federal funds market on a given day. This participation variable can be used as a dependent variable in a fixed-effect logit estimation to explore whether the propensity to participate in the funds market varies on particular dates, especially at yearend. The results of this estimation are given in Table 4, with the first column reporting the results for federal funds borrowing and the second column reporting the results for federal funds lending. 
Figure 2

Participation rates in the funds market

Conditional on at least one day of participation

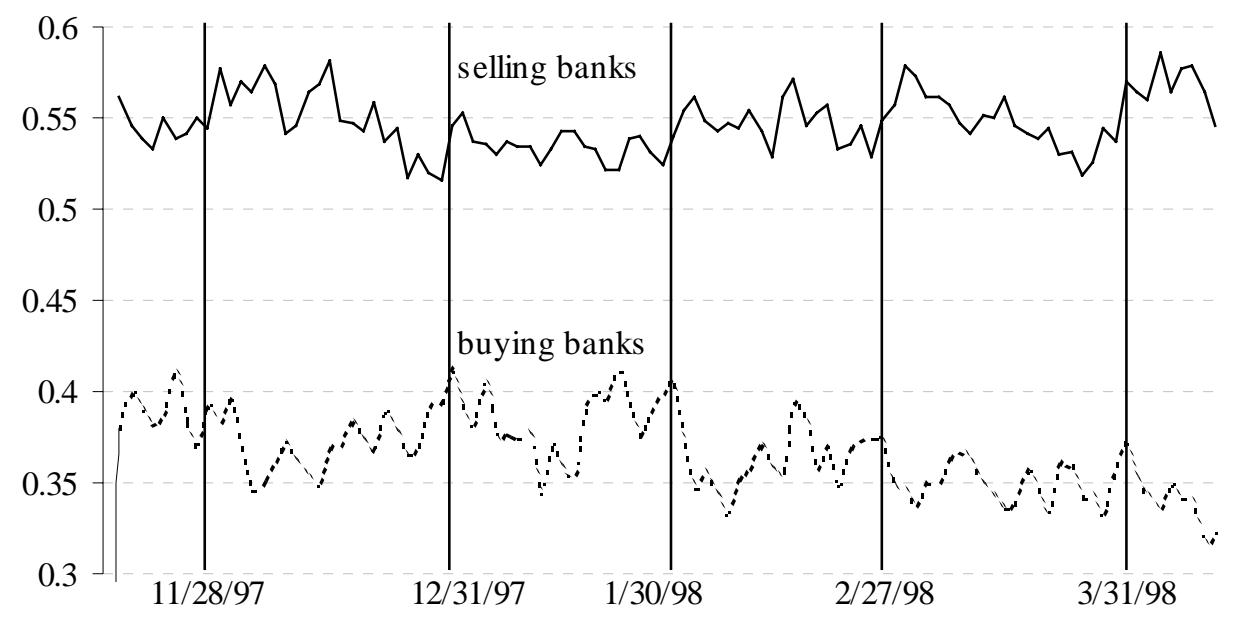

Figure 3

\section{Attendance of infrequent market participants}

Banks with ten or fewer days of participation

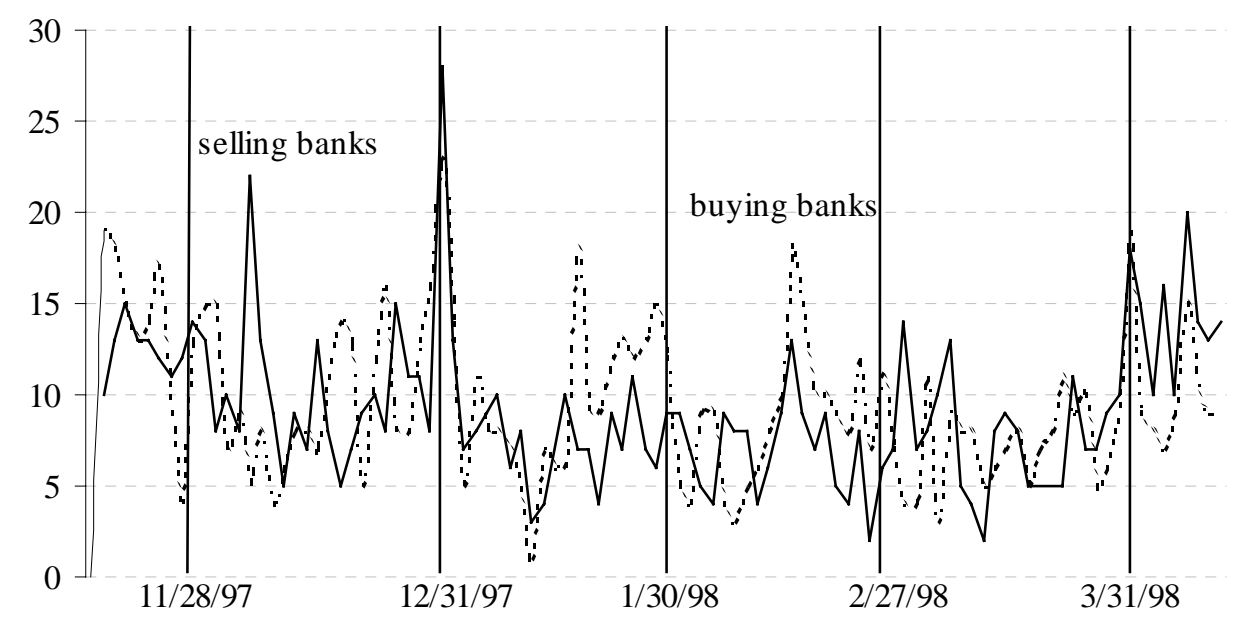

The results indicate a strong and predictable relationship between a bank's daily liquidity needs and participation in the funds market. For example, the higher the number of payments unrelated to the funds market that the bank sends, the more likely the bank is to be a funds borrower and the less likely it is to be a federal funds seller. The higher the number of payments unrelated to federal funds that the bank receives, the less likely a bank is to borrow and the more likely it is to lend in the funds market that day. Maintenance period dummy variables do not generally enter significantly, with the exception of the slight tendency for banks to borrow less and lend more on Fridays. This result is consistent with Hamilton's (1996) interpretation that borrowing before a weekend may be costly because the reserves 
count for three days and thus any excess reserve position is more difficult to unwind later in the reserve maintenance period. The results for the dummy variables representing calendar effects are further supportive of an important relationship between year-end and participation. On 31 December 1997, banks were more likely to both buy and sell funds. Banks are also more likely to borrow at the end of the month, but these dates do not correlate with a higher likelihood of selling funds.

Table 4

\section{Calendar patterns to participation in the federal funds market} Fixed-effect logit estimates

\begin{tabular}{|c|c|c|}
\hline Dependent variable equals 1 when: & $\begin{array}{l}\text { Bank lends in the funds } \\
\text { market }\end{array}$ & $\begin{array}{l}\text { Bank borrows in the funds } \\
\text { market }\end{array}$ \\
\hline \multirow[t]{2}{*}{ Log (Value of non-federal-funds payments sent) } & -0.742 & 0.331 \\
\hline & $(0.012)^{* *}$ & $(0.022)^{* *}$ \\
\hline \multirow[t]{2}{*}{ Log (Value of non-federal-funds payments received) } & 0.258 & -0.432 \\
\hline & $(0.011)^{* *}$ & $(0.021)^{* *}$ \\
\hline \multirow[t]{2}{*}{ Day before 1 day holiday } & -0.121 & 0.002 \\
\hline & $(0.077)$ & $(0.108)$ \\
\hline \multirow[t]{2}{*}{ Day before 3 day holiday } & -0.033 & -0.025 \\
\hline & $(0.079)$ & $(0.114)$ \\
\hline \multirow[t]{2}{*}{ Day after 1 day holiday } & -0.287 & 0.052 \\
\hline & $(0.084)^{* *}$ & $(0.117)$ \\
\hline \multirow[t]{2}{*}{ Day after 3 day holiday } & -0.043 & 0.372 \\
\hline & $(0.081)$ & $(0.112)^{* *}$ \\
\hline \multirow[t]{2}{*}{31 March 1998} & 0.435 & 0.121 \\
\hline & $(0.104)^{* *}$ & $(0.144)$ \\
\hline \multirow[t]{2}{*}{1 April 1998} & 0.465 & -0.161 \\
\hline & $(0.104)^{* *}$ & $(0.148)$ \\
\hline \multirow[t]{2}{*}{31 December 1997} & 0.272 & 0.484 \\
\hline & $(0.127)^{*}$ & $(0.173)^{* *}$ \\
\hline \multirow[t]{2}{*}{2 January 1998} & 0.414 & 0.344 \\
\hline & $(0.140)^{* *}$ & $(0.193)^{*}$ \\
\hline \multirow[t]{2}{*}{$15^{\text {th }}$ of the month } & 0.258 & -0.058 \\
\hline & $(0.049)^{* *}$ & $(0.070)$ \\
\hline \multirow[t]{2}{*}{ First day of non-quarter-beginning months } & 0.288 & -0.021 \\
\hline & $(0.063)^{* *}$ & $(0.089)$ \\
\hline \multirow[t]{2}{*}{ Last day of non-quarter-ending months } & 0.106 & 0.353 \\
\hline & $(0.069)$ & $(0.096)^{* *}$ \\
\hline \multirow[t]{2}{*}{ Good Friday } & -0.133 & -0.490 \\
\hline & $(0.106)$ & $(0.159)^{* *}$ \\
\hline \multicolumn{3}{|l|}{ Days of the reserve maintenance period } \\
\hline \multirow[t]{2}{*}{ First Thursday } & -0.156 & -0.079 \\
\hline & $(0.048)^{* *}$ & $(0.068)$ \\
\hline \multirow[t]{2}{*}{ First Friday } & 0.025 & -0.119 \\
\hline & $(0.055)$ & $(0.078)$ \\
\hline \multirow[t]{2}{*}{ First Monday } & -0.073 & 0.067 \\
\hline & $(0.053)$ & $(0.074)$ \\
\hline First Tuesday & Baseline & Baseline \\
\hline
\end{tabular}


Table 4 (cont.)

\begin{tabular}{lcc}
\hline First Wednesday & -0.077 & 0.009 \\
& $(0.052)$ & $(0.072)$ \\
Second Thursday & -0.053 & -0.099 \\
& $(0.050)$ & $(0.071)$ \\
Second Friday & 0.030 & -0.135 \\
& $(0.050)$ & $(0.071)^{*}$ \\
Second Monday & -0.089 & 0.073 \\
& $(0.048)^{*}$ & $(0.067)$ \\
Second Tuesday & -0.091 & 0.038 \\
& $(0.047)^{*}$ & $(0.065)$ \\
Second Wednesday (settlement day) & -0.086 & 0.024 \\
Observations & $(0.048)^{*}$ & $(0.067)$ \\
Standard errors in parentheses. & 93235 & 55624 \\
$*$ significant at 5\% level; ** significant at 1\% level. & & \\
\hline
\end{tabular}

The results of Table 4 suggest that one may wish to account for the changing participants in the market when trying to explain the cross-sectional variation in federal funds transactions. To account for this, Table 5 replicates the estimation of Table 2 but using a restricted sample of transactions between institutions that participated in the market on at least 50 of the 100 business days. Although this subset of the data eliminates fewer than $10 \%$ of the total number of transactions, it does eliminate 361 of 791 selling institutions (46\%) and 244 of 385 buying institutions (63\%). As Table 5 indicates, however, there is little significant difference from the estimated coefficients reported in Table 2. The four variables that proxy for borrower risk indicate that the economically and statistically significant increase in the price of risk at year-end remains. Thus, the results suggest that sample biases arising from changes in the underlying participants in the market are not obviously responsible for the estimated large increase in the price of risk around particular calendar dates, and especially around year-end.

Table 5

Calendar variation in the pricing of risk in the federal funds market Active market participants only

\begin{tabular}{lc|cccccc}
\hline & & \multicolumn{5}{c}{ Coefficients represent differences from normal } \\
& Normal & 31 December & 31 March & Month-ends & Settlement & High payment \\
days & 1997 & 1998 & & & days & \\
days & & & & & & & \\
Borrower characteristics & & & & & & & \\
Return on assets & -1.107 & -24.232 & -12.926 & -0.998 & -1.820 & -2.387 \\
& $(0.244)^{* *}$ & $(7.266)^{* *}$ & $(4.060)^{* *}$ & $(1.436)$ & $(1.319)$ & $(0.506)^{* *}$ \\
Nonaccruing loans & 0.047 & 22.461 & -4.214 & 4.837 & 0.504 & 0.478 \\
& $(0.309)$ & $(9.300)^{*}$ & $(3.993)$ & $(2.094)^{*}$ & $(1.463)$ & $(0.686)$ \\
Risk-based capital ratio & -0.389 & -0.760 & -0.425 & -0.154 & -0.029 & -0.208 \\
& $(0.049)^{* *}$ & $(1.650)$ & $(0.906)$ & $(0.396)$ & $(0.246)$ & $(0.135)$ \\
Log (ratio of transaction size to capital) & 0.006 & 0.101 & 0.066 & 0.022 & -0.008 & 0.016 \\
& $(0.001)^{* *}$ & $(0.029)^{* *}$ & $(0.013)^{* *}$ & $(0.007)^{* *}$ & $(0.007)$ & $(0.002)^{* *}$
\end{tabular}


Table 5 (cont.)

\begin{tabular}{|c|c|c|c|c|c|c|}
\hline Market share & $\begin{array}{c}-0.008 \\
(0.035)\end{array}$ & $\begin{array}{l}5.189 \\
(1.472)^{* *}\end{array}$ & $\begin{array}{c}1.568 \\
(0.479)^{* *}\end{array}$ & $\begin{array}{l}0.427 \\
(0.144)^{* *}\end{array}$ & $\begin{array}{c}-0.326 \\
(0.209)\end{array}$ & $\begin{array}{l}0.239 \\
(0.062)^{* *}\end{array}$ \\
\hline Assets $<\$ 250$ million & $\begin{array}{c}0.158 \\
(0.024)^{* *}\end{array}$ & $\begin{array}{l}-0.617 \\
(0.275)^{*}\end{array}$ & $\begin{array}{c}-0.133 \\
(0.139)\end{array}$ & $\begin{array}{c}-0.086 \\
(0.072)\end{array}$ & $\begin{array}{c}0.029 \\
(0.059)\end{array}$ & $\begin{array}{l}-0.115 \\
(0.036)^{* *}\end{array}$ \\
\hline Assets $\$ 250$ million - $\$ 1$ billion & $\begin{array}{c}0.100 \\
(0.008)^{* * *}\end{array}$ & $\begin{array}{c}0.102 \\
(0.208)\end{array}$ & $\begin{array}{c}-0.048 \\
(0.139)\end{array}$ & $\begin{array}{c}0.024 \\
(0.040)\end{array}$ & $\begin{array}{c}0.014 \\
(0.036)\end{array}$ & $\begin{array}{l}-0.016 \\
(0.020)\end{array}$ \\
\hline Assets $\$ 1$ - $\$ 10$ billion & $\begin{array}{c}-0.004 \\
(0.004)\end{array}$ & $\begin{array}{c}0.121 \\
(0.124)\end{array}$ & $\begin{array}{c}-0.037 \\
(0.056)\end{array}$ & $\begin{array}{c}-0.026 \\
(0.025)\end{array}$ & $\begin{array}{c}0.015 \\
(0.025)\end{array}$ & $\begin{array}{l}-0.029 \\
(0.009)^{* *}\end{array}$ \\
\hline Assets $\$ 10$ - $\$ 100$ billion & $\begin{array}{l}-0.023 \\
(0.004)^{* *}\end{array}$ & $\begin{array}{c}0.012 \\
(0.085)\end{array}$ & $\begin{array}{c}-0.036 \\
(0.037)\end{array}$ & $\begin{array}{c}-0.015 \\
(0.016)\end{array}$ & $\begin{array}{c}0.007 \\
(0.019)\end{array}$ & $\begin{array}{l}-0.015 \\
(0.007)^{*}\end{array}$ \\
\hline Assets $>\$ 100$ billion & & Baseline & & & & \\
\hline Dealer bank & $\begin{array}{c}0.008 \\
(0.003)^{*}\end{array}$ & $\begin{array}{c}-0.094 \\
(0.100)\end{array}$ & $\begin{array}{l}-0.116 \\
(0.041)^{* *}\end{array}$ & $\begin{array}{l}-0.064 \\
(0.017)^{* *}\end{array}$ & $\begin{array}{c}0.008 \\
(0.020)\end{array}$ & $\begin{array}{l}-0.036 \\
(0.006)^{* *}\end{array}$ \\
\hline Net inflow of payments & $\begin{array}{c}-0.008 \\
(0.003)\end{array}$ & $\begin{array}{c}-0.158 \\
(0.094)\end{array}$ & $\begin{array}{l}-0.152 \\
(0.070)^{*}\end{array}$ & $\begin{array}{c}0.003 \\
(0.016)\end{array}$ & $\begin{array}{c}-0.023 \\
(0.015)\end{array}$ & $\begin{array}{c}0.018 \\
(0.006)^{* *}\end{array}$ \\
\hline \multicolumn{7}{|l|}{ Lender characteristics } \\
\hline Market share & $\begin{array}{l}-0.216 \\
(0.044) * *\end{array}$ & $\begin{array}{c}-0.472 \\
(0.869)\end{array}$ & $\begin{array}{c}0.052 \\
(0.330)\end{array}$ & $\begin{array}{c}0.401 \\
(0.227)\end{array}$ & $\begin{array}{l}-0.431 \\
(0.192)^{*}\end{array}$ & $\begin{array}{l}-0.454 \\
(0.078)^{* *}\end{array}$ \\
\hline Assets $<\$ 250$ million & $\begin{array}{l}-0.102 \\
(0.007) * *\end{array}$ & $\begin{array}{l}-0.265 \\
(0.143)\end{array}$ & $\begin{array}{c}0.003 \\
(0.063)\end{array}$ & $\begin{array}{c}0.140 \\
(0.038)^{* *}\end{array}$ & $\begin{array}{l}-0.103 \\
(0.041)^{*}\end{array}$ & $\begin{array}{c}-0.001 \\
(0.013)\end{array}$ \\
\hline Assets $\$ 250$ million - $\$ 1$ billion & $\begin{array}{l}-0.110 \\
(0.007)^{* *}\end{array}$ & $\begin{array}{l}-0.434 \\
(0.146)^{* *}\end{array}$ & $\begin{array}{c}-0.024 \\
(0.059)\end{array}$ & $\begin{array}{l}0.128 \\
(0.037)^{* *}\end{array}$ & $\begin{array}{l}-0.116 \\
(0.041)^{* *}\end{array}$ & $\begin{array}{c}-0.002 \\
(0.013)\end{array}$ \\
\hline Assets $\$ 1$ - $\$ 10$ billion & $\begin{array}{l}-0.082 \\
(0.007)^{* *}\end{array}$ & $\begin{array}{c}-0.278 \\
(0.142)\end{array}$ & $\begin{array}{c}-0.012 \\
(0.055)\end{array}$ & $\begin{array}{l}0.108 \\
(0.035)^{* *}\end{array}$ & $\begin{array}{l}-0.096 \\
(0.040)^{*}\end{array}$ & $\begin{array}{c}-0.008 \\
(0.012)\end{array}$ \\
\hline Assets $\$ 10-\$ 100$ billion & $\begin{array}{c}-0.011 \\
(0.007)\end{array}$ & $\begin{array}{c}-0.031 \\
(0.109)\end{array}$ & $\begin{array}{c}0.047 \\
(0.043)\end{array}$ & $\begin{array}{c}0.049 \\
(0.029)\end{array}$ & $\begin{array}{l}-0.076 \\
(0.036)^{*}\end{array}$ & $\begin{array}{c}-0.013 \\
(0.011)\end{array}$ \\
\hline Assets $>\$ 100$ billion & & Baseline & & & & \\
\hline Dealer bank & $\begin{array}{c}0.002 \\
(0.006)\end{array}$ & $\begin{array}{l}-0.246 \\
(0.098)^{*}\end{array}$ & $\begin{array}{c}0.007 \\
(0.037)\end{array}$ & $\begin{array}{c}0.006 \\
(0.025)\end{array}$ & $\begin{array}{c}0.007 \\
(0.031)\end{array}$ & $\begin{array}{c}0.009 \\
(0.010)\end{array}$ \\
\hline Net inflow of payments & $\begin{array}{c}0.000 \\
(0.001)^{* *}\end{array}$ & $\begin{array}{c}-0.075 \\
(0.060)\end{array}$ & $\begin{array}{c}-0.002 \\
(0.006)\end{array}$ & $\begin{array}{c}0.004 \\
(0.005)\end{array}$ & $\begin{array}{l}-0.015 \\
(0.005)^{* *}\end{array}$ & $\begin{array}{l}0.009 \\
(0.001)^{* *}\end{array}$ \\
\hline \multicolumn{7}{|l|}{ Transaction Characteristics } \\
\hline Business hours duration & $\begin{array}{l}0.007 \\
(0.001)^{* * *}\end{array}$ & $\begin{array}{c}0.016 \\
(0.010)\end{array}$ & $\begin{array}{c}0.003 \\
(0.005)\end{array}$ & $\begin{array}{l}-0.006 \\
(0.003)^{*}\end{array}$ & $\begin{array}{c}0.003 \\
(0.002)\end{array}$ & $\begin{array}{c}0.001 \\
(0.001)\end{array}$ \\
\hline Trans size less than or equal to $\$ 10 \mathrm{mil}$. & & Baseline & & & & \\
\hline \multirow[t]{2}{*}{$\begin{array}{l}\text { Trans size between } \$ 10 \text { mil and } \$ 100 \\
\text { mil. }\end{array}$} & 0.009 & 0.162 & -0.002 & 0.048 & 0.004 & 0.003 \\
\hline & $(0.002)^{* *}$ & $(0.068)^{*}$ & $(0.027)$ & $(0.011)^{* *}$ & $(0.010)$ & $(0.005)$ \\
\hline Trans size greater than $\$ 100$ mil. & $\begin{array}{l}-0.027 \\
(0.005)^{* *}\end{array}$ & $\begin{array}{c}0.015 \\
(0.132)\end{array}$ & $\begin{array}{l}-0.117 \\
(0.076)\end{array}$ & $\begin{array}{c}0.045 \\
(0.025)\end{array}$ & $\begin{array}{c}0.019 \\
(0.022)\end{array}$ & $\begin{array}{l}-0.018 \\
(0.010)\end{array}$ \\
\hline Observations & 131576 & 1954 & 1941 & 5237 & 18034 & 18106 \\
\hline R-squared & 0.14 & 0.29 & 0.23 & 0.14 & 0.08 & 0.43 \\
\hline \multicolumn{7}{|l|}{ Robust standard errors in parentheses } \\
\hline A description of all variables included in the & regressi & & le A1 i & Append & & \\
\hline
\end{tabular}




\section{Summary and conclusion}

The results of this paper document that the federal funds market exhibits a significant increase in the price of risk at year-end. The findings are similar to the basic findings of Griffiths and Winters (1997) in repo markets and of Musto (1997) in commercial paper markets. However, the repricing of risk in the funds market apparently does not occur solely because of liquidity needs or of the tendency of some banks to use the funds market to window dress. The size of the repricing of risk is also significant economically. Risky banks that generally pay a risk premium of a few basis points pay nearly a full percentage point more than safe banks at year-end. 


\section{Appendix}

\section{Table A1}

Definitions of variables used in Tables 2 and 5

Borrower's credit risk

Return on assets

Nonaccruing loans

Risk-based capital ratio

Log (Trans size to capital ratio)
Net income divided by total assets.

Nonaccruing loans as a fraction of total loans.

Total capital as a fraction of risk-weighted assets.

The natural log of transaction size as a fraction of total capital.

Other institution characteristics (for both borrowing and lending bank)

Market share

Assets $<\$ 250 \mathrm{~m}$

Assets between $\$ 250 \mathrm{~m}$ and $\$ 1 \mathrm{~b}$

Assets between $\$ 1 \mathrm{~b}$ and $\$ 10 \mathrm{~b}$

Assets between $\$ 10 \mathrm{~b}$ and $\$ 100 \mathrm{~b}$

Assets over $\$ 100 \mathrm{~b}$

Dealer bank

Net inflow of payments
Share of the day's total borrowing (or lending) of the given institution.

Indicator variables reflecting the borrower's or lender's total assets.
Indicator variable representing a bank that bought and sold at least $\$ 1$ billion of federal funds during each of the 61 days of the sample period.

Total Fedwire value received minus total Fedwire value sent divided by the bank's total Fedwire value sent and received.

Transaction Characteristics (not reported)

Trans $<=\$ 10 \mathrm{~m}$

Trans between $\$ 10 \mathrm{~m}$ and $\$ 100 \mathrm{~m}$

Trans over $\$ 100 \mathrm{~m}$

Business hours duration

Time-of-day dummies

Day dummies
Indicator variables reflecting the size of the federal funds transaction.

The number of Fedwire operating hours between delivery of the federal funds sold and the return of the funds with interest.

Indicator variables reflecting the time of day the initial delivery of funds sold was made.

Indicator variables reflecting the day of the sample period. 


\section{References}

Allen, Linda and Anthony Saunders (1992): "Bank window dressing: Theory and evidence". Journal of Banking and Finance, Vol. 16, pp. 585-623.

Badrinath, S G and Wilbur G Lewellen (1991): "Evidence on Tax-Motivated Securities Trading Behavior". The Journal of Finance, Vol. 46, pp. 369-82.

Federal Reserve Bank of New York (1987): “A Study of Large-Dollar Payment Flows through CHIPS and Fedwire".

Furfine, Craig H (1999): "The pricing of bank lending and borrowing: evidence from the Federal funds market". BIS Working Paper No. 62.

Furfine, Craig H (1998): "Interbank Payments and the Daily Federal Funds Rate". Finance and Economics Discussion Series 1998-31, Federal Reserve Board of Governors.

Givoly, Dan and Arie Ovadia (1983): "Year-End Tax-Induced Sales and Stock Market Seasonality". The Journal of Finance, Vol. 38, pp. 171-85.

Griffiths, Mark D and Robert W White (1993): "Tax-Induced Trading and the Turn-of-the-Year Anomaly: An Intraday Study”. The Journal of Finance, Vol. 48, pp. 575-98.

Griffiths, Mark D and Drew B Winters (1997): "On a Preferred Habitat for Liquidity at the Turn-ofthe-Year: Evidence from the Term-Repo Market". Journal of Financial Services Research, Vol. 12, pp. 21-38.

Gultekin, Mustafa N and N Bulent Gultekin (1983): "Stock Market Seasonality: International Evidence". Journal of Financial Economics, Vol. 12, pp. 469-81.

Hamilton, James D (1996): "The Daily Market for Federal Funds". Journal of Political Economy, Vol. 104, pp. 26-56.

Haugen, Robert A. and Josef Lakonishok (1988): The Incredible January Effect. Dow Jones-Irwin.

Jones, Charles P, Douglas K Pearce and Jack W Wilson (1987): "Can Tax-Loss Selling Explain the January Effect? A Note". The Journal of Finance, Vol. 42, pp. 453-61.

Keim, Donald B (1983): "Size-Related Anomalies and Stock Return Seasonality: Further Empirical Evidence". Journal of Financial Economics, Vol. 12, pp. 13-32.

Musto, David K (1999): "Investment Decisions Depend on Portfolio Disclosures". The Journal of Finance, Vol. 54, pp. 935-52.

Musto, David K (1997): "Portfolio Disclosures and Year-End Price Shifts". The Journal of Finance, Vol. 52, pp. 1563-88.

Ogden, Joseph P (1987): "The End of the Month as a Preferred Habitat: A Test of Operational Efficiency in the Money Market". Journal of Financial and Quantitative Analysis, Vol. 22, pp. 329-43.

Ogden, Joseph P (1990): "Turn-of-Month Evaluations of Liquid Profits and Stock Returns: A Common Explanation for the Monthly and January Effects". The Journal of Finance, Vol. 45, pp. 1259-72.

Park, Sang Yong and Marc R Reinganum (1986): "The Puzzling Price Behavior of Treasury Bills that Mature at the Turn of Calendar Months". Journal of Financial Economics, Vol. 16, pp. 267-83.

Sias, Richard W and Laura T Starks (1997): "Institutions and Individuals at the Turn-of-the-Year". The Journal of Finance, Vol. 52, pp. 1543-62. 




\section{Recent BIS Working Papers}

No.

60

November 1998

61

November 1998

62

March 1999

63

March 1999

64

March 1999

65

April 1999

66

April 1999

67

May 1999

68

May 1999

69

June 1999

70

June 1999

71

June 1999

72

August 1999

73

August 1999

74

August 1999

75

August 1999
Title

Output gap uncertainty: does it matter for the Taylor rule?

Foreign direct investment and employment in the industrial countries

The pricing of bank lending and borrowing: evidence from the federal funds market

Microeconomic inventory adjustment and aggregate

dynamics

Precarious credit equilibria: reflections on the Asian financial crisis

Higher profits and lower capital prices: is factor allocation optimal?

Evolving international financial markets: some implications for central banks

The cyclical sensitivity of seasonality in US employment

The evolution and determinants of emerging market credit spreads in the 1990s

Credit channels and consumption in Europe: empirical evidence

Interbank exposures: quantifying the risk of contagion

The term structure of announcement effects

Reserve currency allocation: an alternative methodology

The Taylor rule and interest rates in the EMU area: a note

The dollar-mark axis

A note on the Gordon growth model with nonstationary dividend growth
Author

Frank Smets

P S Andersen

and $\mathrm{P}$ Hainaut

Craig H Furfine

Jonathan McCarthy and Egon Zakrajšek

Joseph Bisignano

P S Andersen, M Klau and E Yndgaard

William R White

Spencer Krane and

William Wascher

Steven B Kamin and Karsten von Kleist

Gabe de Bondt

Craig H Furfine

Michael J Fleming and Eli M Remolona

Srichander

Ramaswamy

Stefan Gerlach and

Gert Schnabel

Gabriele Galati

Henri Pagès 